\title{
U-PB DATING OF DETRITAL ZIRCON FROM TURBIDITES OF THE CHUGACH AND PRINCE WILLIAM TERRANES, ALASKA: SIGNIFICANCE OF THE CONTACT FAULT SYSTEM AS A TERRANE BOUNDARY
}

ALYSALA MALIK, Carleton College

Research Advisor: Cameron Davidson

\section{INTRODUCTION}

The Gulf of Alaska is rimmed by a MesozoicCenozoic accretionary wedge complex comprised of the Chugach and the Prince William terranes. This study focuses on understanding the history and relationship between turbidites of the Chugach and Prince William terranes in the Prince William Sound area: the Campanian-Maastrichtian Valdez Group and the Paleocene-Eocene Orca Group. Critical in understanding this system is the Contact fault system, a poorly understood collection of fault strands that has traditionally been viewed as the terrane boundary between the two (Winkler and Plafker 1975; Plafker et al. 1977; Tysdal and Case 1979; Dumoulin 1988; Bol and Gibbons 1992; Bol and Roeske 1993; Arkle et al. 2013). It was thought to be an original accretionary fault that separates terranes (Plafker et al. 1977; Nokleberg et al., 1986; Dumoulin, 1988); however, more recent work has characterized it as a sequence of faults that may be related to internal deformation of the accretionary complex (Bol and Gibbons, 1992; Bol and Roeske, 1993).

The main goal of this study is to determine whether the Contact fault functions as a terrane boundary across Prince William Sound by presenting new detrital zircon $\mathrm{U}-\mathrm{Pb}$ ages from either side of the fault system (Fig. 1). First, we specifically focus on understanding the age relationships between the Valdez Group and the Orca Group on either side of the Jack Bay fault and the Landlock fault in Valdez Arm, northeastern Prince William Sound (Fig. 2). Second, we focus on strands of the Contact fault system in three other locations: Unakwik Inlet, Kings Bay, and Seward (Fig. 3).

This second goal of this study is to determine the nature of the Landlock block, an area currently defined by the convergence of the Jack Bay and Landlock faults (Fig. 2). Early maps portrayed the Landlock block as Valdez Group (Moffit, 1954; Winkler and Plafker, 1975), but the current location of the Contact fault in Jack Bay includes the block as part of the Orca Group (Dumoulin, 1998; Bol and Roeske, 1993). Therefore, an important question is the affinity of the rocks of the Landlock block, whether they are Orca Group or Valdez Group.

\section{GEOLOGIC SETTING}

\section{Northeastern Prince William Sound}

In northeastern PWS near Valdez, the segments of the Contact fault of interest are the Jack Bay and Landlock Faults. The two faults divide the area into three lithotectonic belts that have been reported to differ in structural trends, deformation intensities, and metamorphic grade (Fig. 2; Bol and Roeske 1993). The Jack Bay fault is currently mapped as the contact between the Chugach and Prince William terranes, separating the Valdez Group and the Orca Group (Fig. 2; Dumoulin, 1998; Bol and Roeske, 1993; Wilson et al., 2015). The Jack Bay fault is also mapped as the northern edge of the Landlock block, an area defined by the convergence of the high-angle Jack Bay fault with the low-angle Landlock fault (Fig. 2). The Landlock block has been characterized 


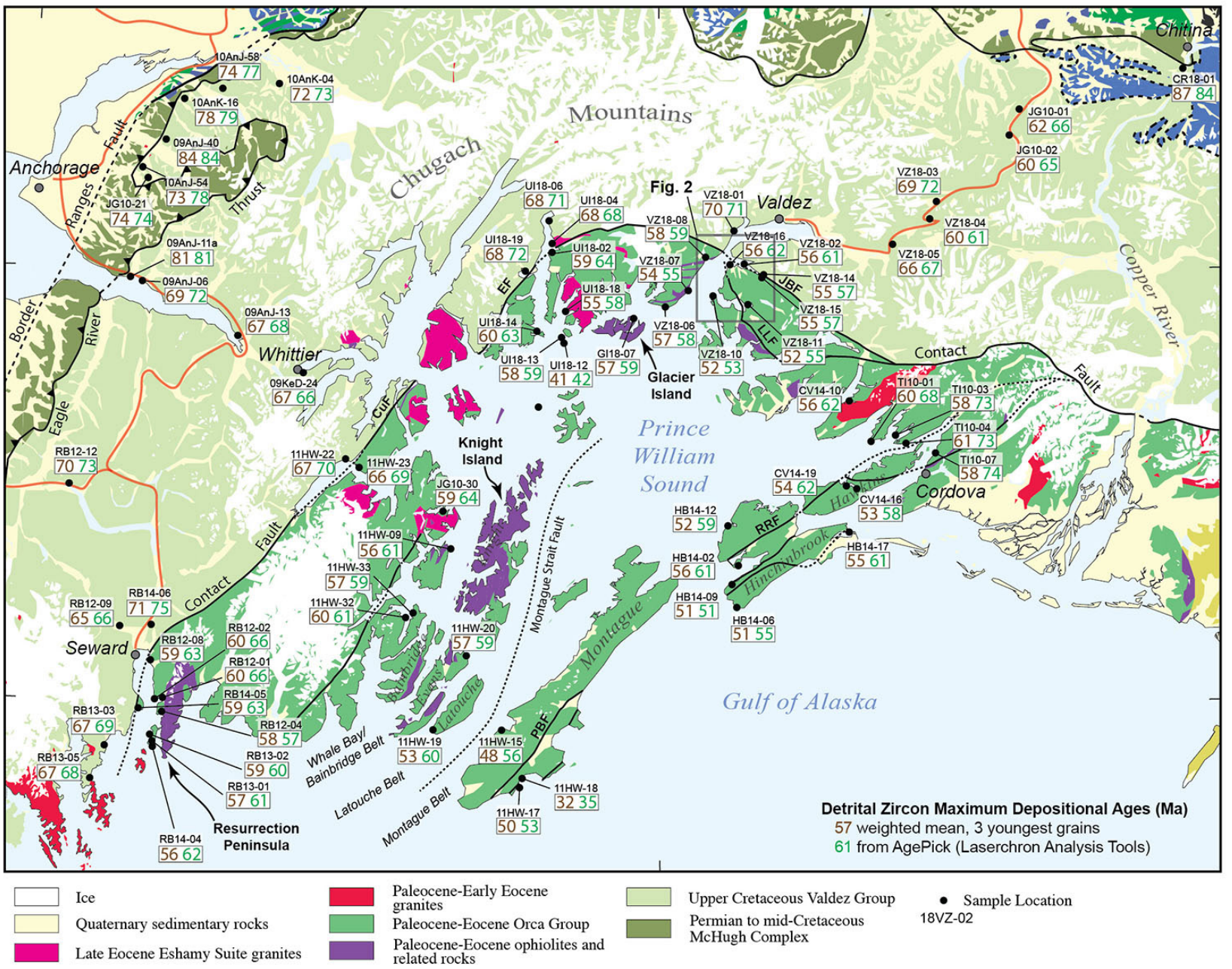

Figure 1. Geologic map of Prince William Sound, Alaska (modified from Bradley and Miller, 2006). CuF = Culross fault, EF= Eaglek fault, JBF = Jack Bay fault, LLF = Landlock fault.

by massive sandstone units with units of thinly interbedded sandstone and siltstone turbidites (Bol and Roeske, 1993). The metamorphic grade was mapped as phrenite-pumpellyite and rarely greater than lower greenschist facies, which is lower than surrounding units (Bol and Roeske, 1993). North of the Jack Bay fault the rocks are mainly fine-grained graywacke sandstones with greenschist facies mapped as the highest metamorphic grade (Bol and Roeske, 1993). However, in the field we observed that the north shore of the Landlock block was indistinguishable from massive, coarse-grained sandstone units north of the Jack Bay fault. It was only farther south in Galena Bay that we observed characteristic Landlock block outcrops of thinly bedded, medium-fine sandstone turbidites interbedded with shale (sample VZ18-11, Fig. 2).

\section{Northern Prince William Sound}

In northern PWS, the Eaglek fault is the fault strand mapped as juxtaposing the Prince William and Chugach terranes (Fig. 3; Tysdal and Case 1979; Nelson et al. 1985). It is visible as a deformation zone 10 to 100 meters wide that begins at Unakwik Inlet, passes through Eaglek Bay, and becomes obscured after Esther Island (Bol and Gibbons 1992; Plafter et al. 1977). The age of the fault is constrained by a cross-cutting relationship with the 41 Ma Miner's Bay pluton (Garcia et al., 2019).

\section{Western and Southwestern Prince William Sound}

The location of the Contact fault has been difficult to define in western Prince William Sound because of similarities in lithology and structure of the Valdez and Orca Groups (Tysdal and Case, 1979; Dumoulin, 


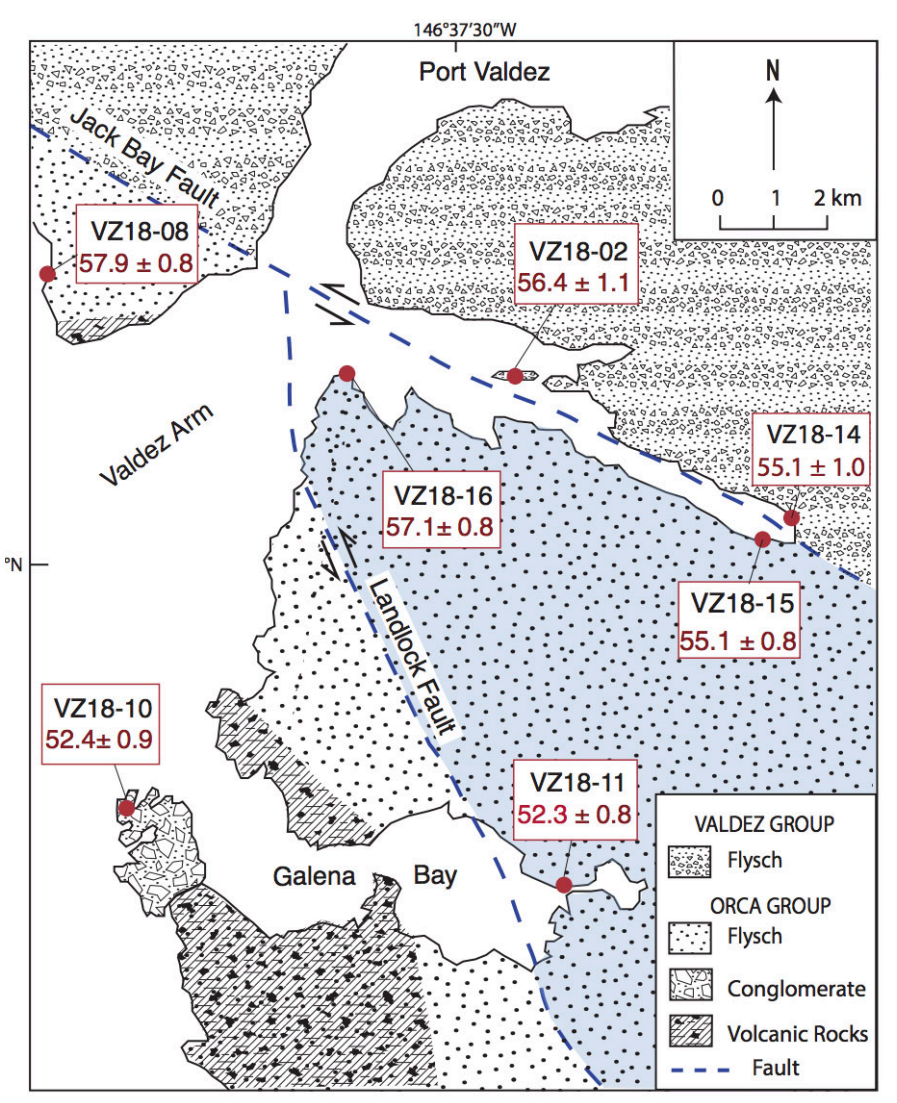

Figure 2. Geologic map of Valdez Arm in northeastern Prince William Sound. The Jack Bay and Landlock faults, sample locations, and geologic units are shown. Maximum depositional ages (MDAs) based on the weighted mean of the youngest three zircons are shown in red. All samples yielded Orca Group MDAs (Paleocene-Eocene). Adapted from Bol and Roeske (1993).

1988; Bol and Gibbons, 1992; Davidson and Garver, 2017). The Culross fault was originally mapped as the terrane-bounding segment of the Contact fault system (Tysdal and Case, 1979; Bol and Gibbons, 1992). The fault itself is highly obscured in locations such as Long Bay (west of Culross Pass) while extremely visible and located to within a few meters farther northeast (Fig. 3; Bol and Gibbons, 1992). The fault was initially mapped as a southern extension of the Eaglek fault (Tysdal and Case, 1979), however this has been disproven (Bol and Gibbons, 1992).

Similarly to western Prince William Sound, the location of the Contact fault has been difficult to define in southwest Prince William Sound. The fault was originally mapped along the Resurrection Peninsula (Tysdal and Case, 1979), however a recent study suggested that the Contact fault belongs along the western edge of Resurrection Bay (Davidson and Garver, 2017).

\section{METHODS}

Detrital zircon $\mathrm{U}-\mathrm{Pb}$ ages were determined from sandstone samples collected along Valdez Arm and and Unakwik Inlet to determine, in part, the age of units on either side of the Jack Bay, Landlock, and Eaglek faults (Figs. 2 \& 3). Zircons were isolated using standard techniques of crushing, grinding, Rogers table, heavy liquids, and magnetic separation at Carleton College. Samples were dated at the Arizona Laserchron Center through Laser Ablation ICP Mass Spectrometry. Maximum depositional ages (MDA) were calculated using two different methods. The first method uses the weighted mean of the youngest three zircons from the youngest age cluster of a sample. The second method uses AgePick, an

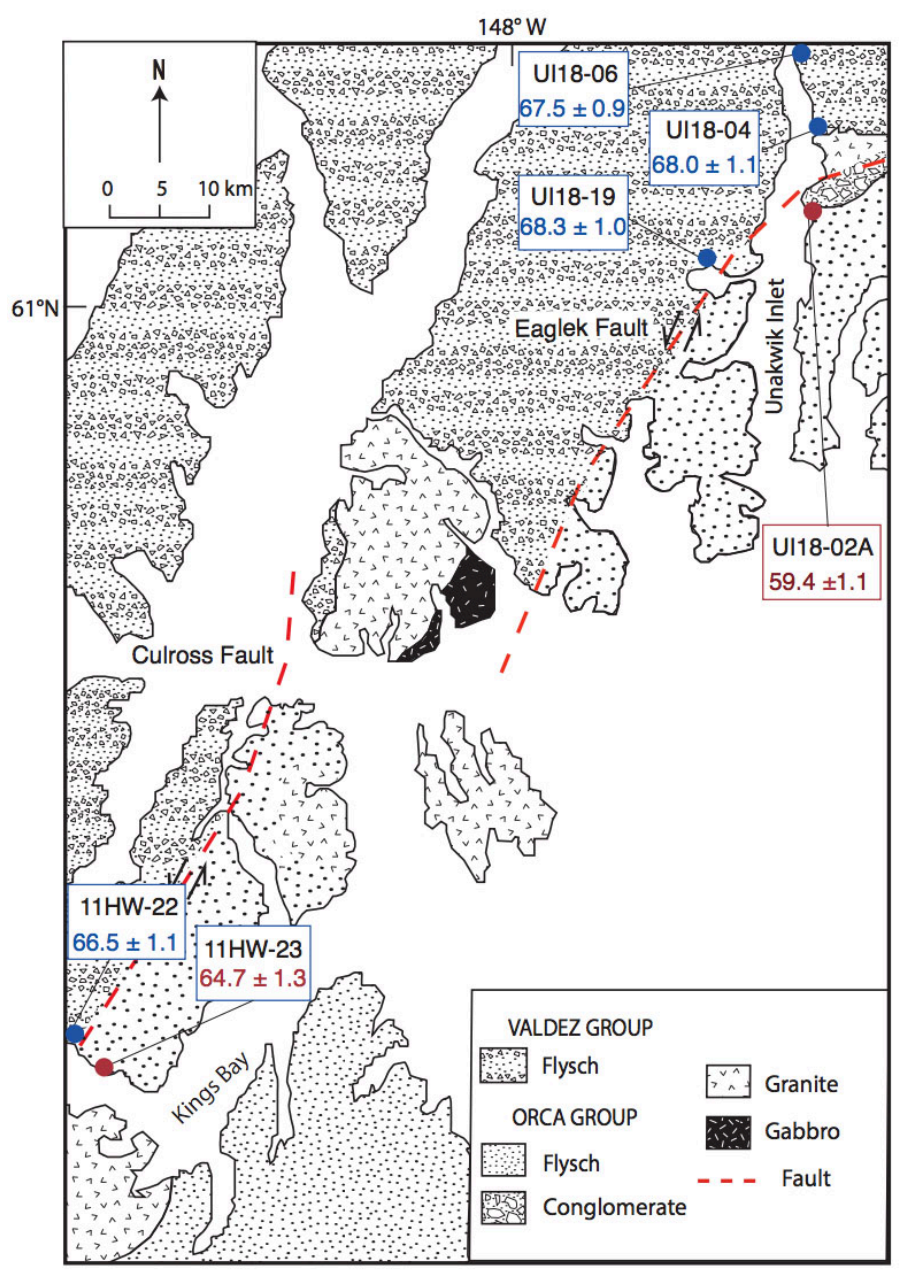

Figure 3. Geologic map of Unakwik Inlet and Kings Bay in northwest Prince William Sound. The Eaglek and Culross faults, sample locations, and geologic units are shown. Samples in red yield Orca Group MDAs (Paleocene-Eocene) while samples in blue yielded Valdez Group MDAs (Upper Cretaceous). Adapted from Bol and Gibbons (1992). 

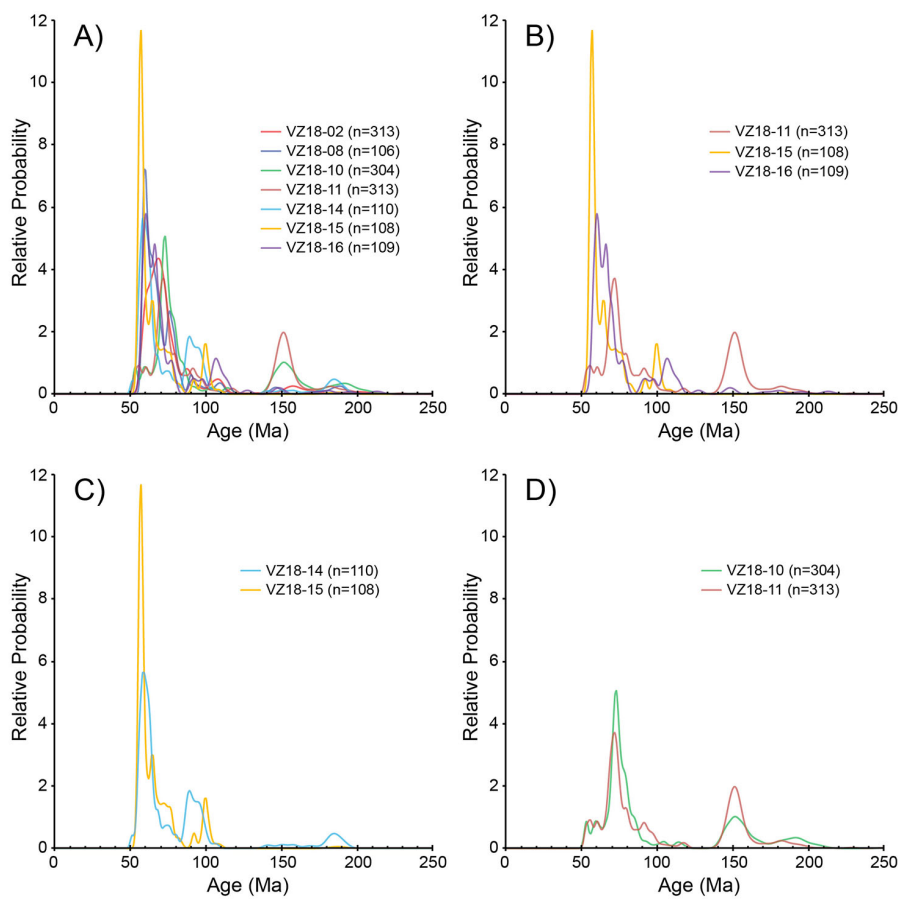

Figure 4. Normalized probability density functions (PDFs) of detrital zircon ages from the Valdez Arm area shown in Figure 2. A) All seven samples from Figure 2. B) Three samples from the Landlock block have different grain-age distributions and fail the K-S test. C) VZ18-14 and 15 from either side of the Jack Bay fault have similar grain-age distributions and pass the $K-S$ test. D) VZ18-10 and 11 from either side of the Landlock fault have remarkably similar grain-age distributions and pass the $K-S$ test.

Excel macro that identifies the youngest coherent peak in a grain-age distribution. The Kolmogorov-Smirnov statistical test (K-S test) was used to analyze whether samples have similar grain-age populations.

\section{RESULTS}

Seven samples collected from either side of the Jack Bay and Landlock faults in the Valdez Arm area yield Paleocene and Eocene MDAs (Fig. 2 \& 4A). The three samples from the Landlock Block (VZ18-15, VZ18-16, and VZ18-11) have different grain-age distributions (Fig. 4B) and failed the K-S test suggesting they were not derived from the same source. Samples taken from either side of Jack Bay fault (VZ18-14 and VZ18-15) give the same MDA $(55.1 \mathrm{Ma})$ and have similar grain-age distributions with a prominent Paleocene peak (57-59 Ma), and another prominent Late Cretaceous peak (90-100 $\mathrm{Ma}$ ) and pass the K-S test (Fig. 4C). Two samples collected on either side of the Landlock fault (VZ1810 and VZ18-11) have nearly identical Eocene MDAs ( $\sim 52 \mathrm{Ma})$, yield remarkably similar grain-age
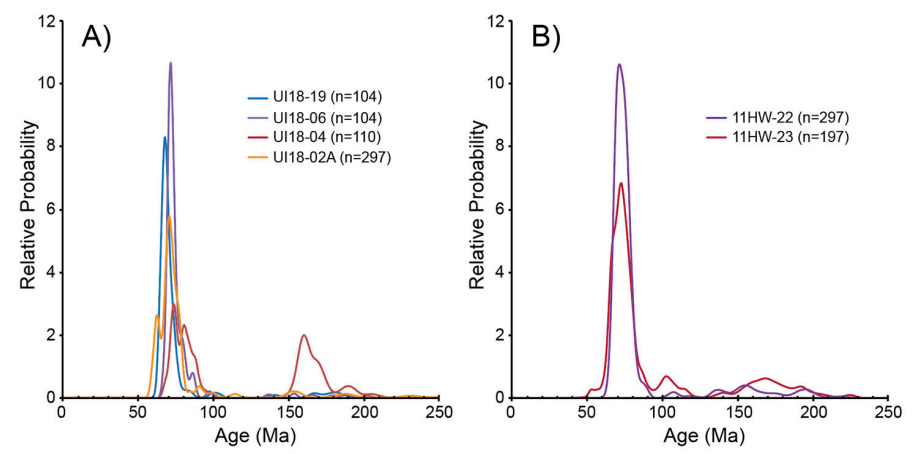

Figure 5. A) UI18-02A taken from the Orca Group side of the Eaglek fault has a Paleocene-Eocene grain-age peak while three samples taken from the Valdez Group side have late Cretaceous grain-age distributions. B) $11 \mathrm{HW}-22$ and 23 from either side of the Culross fault have remarkably similar grain-age distributions, however fail the $K-S$ test.

distributions with prominent Late Cretaceous and Jurassic peaks (Fig. 4D), and pass the K-S test ( $\mathrm{p}=$ $0.412)$.

In Unakwik inlet, UI18-02A taken from the southern side of Eaglek fault yielded a Paleocene MDA of $59.4 \pm 1.1 \mathrm{Ma}$ (Fig. 3). However, three samples taken from the northern side of the fault (UI18-04, UI18-06, and UI18-19) yield Late Cretaceous MDAs of $68.0 \pm$ $1.1,67.5 \pm 0.9$, and $68.3 \pm 1.0 \mathrm{Ma}$ (Fig. $3 \& 4 \mathrm{~A}$ ). In western Prince William Sound, 11HW-22 and 11HW23 occur on either side of the Contact fault but have similar MDAs $(66.5 \pm 1.1 \mathrm{Ma}$ and $64.7 \pm 1.3 \mathrm{Ma})$ and grain-age distributions with a significant Late Cretaceous peak at $73 \mathrm{Ma}$ (Fig. $3 \&$ 5B). 11HW-22 and $11 \mathrm{HW}-23$ do not pass the K-S test $(\mathrm{p}=0.002)$.

\section{DISCUSSION}

Samples were taken from either side of the Jack Bay fault to analyze the relationship between the fault strand and the Valdez and Orca Group. Samples in the Valdez Arm area yield similar Paleocene and Eocene MDAs (Fig. 2) and some of the samples appear to be derived from the same source (Fig. 4). The presence of Orca Group age rocks north of the Jack Bay fault suggests that: a) the Jack Bay fault as mapped is not the boundary between the Chugach and Prince William terranes, or b) there are slivers of Orca Group along the fault zone on the northern arm of Jack Bay. Samples VZ18-02, 08, 14, and 16 have similar grain ages distributions and pass the K-S test; this suggests that there may be a coherent block of similar 
provenance that becomes progressively older moving east to west (Fig. 2).

The similar MDAs and grain-age distributions of VZ18-10 and VZ18-11 on either side of the Landlock fault show that the rocks of the Landlock block are clearly allied with the Orca Group (Fig. 4D). The rocks in Galena Bay are younger than the Orca Group to the north in Jack Bay, but also younger than the Orca Group to south near Cordova (Fig. 1). Grimm (2015) reports similar Eocene age rocks to the south on Hinchinbrook Island (Fig. 1) that are markedly similar to the Orca units seen in Galena Bay (Fig. 2), characterized by thin- to medium-bedded fine sandstone and interbedded shale. Additionally, K-S test results indicate that VZ18-10 and VZ18-11 were drawn from the same population, and that HB1406 and VZ18-11 were also drawn from the same population (at the 95 percent confidence level).

In the Unakwik inlet area (Fig. 3), samples taken from either side of the Eaglek fault yield MDAs and grain-age distributions that show that the Eaglek fault functions as the boundary between the Valdez Group and Orca Group (Fig. 5A). UI18-02A has an MDA of -59 Ma while UI18-04, UI18-06, and UI18-19 yielded Late Cretaceous MDA's of $\sim 68$ Ma (Fig. 3). Results of the K-S test indicate that UI18-06 and UI18-19 were drawn from the same population. Examination of the PDF's of these three samples indicates that UI18-04 has a smaller proportion of Late Cretaceous grains than UI18-06 and UI18-19, which may have affected the results of the K-S test (Fig. 5A).

The location of the Contact fault in western Prince William Sound has been difficult to define due to similarities in appearance and structure of the Valdez and Orca Groups (Tysdale and Case, 1979; Dumoulin, 1988; Bol and Gibbons, 1992). U-Pb results from 11HW-22 and 11HW-23 collected on either side of the Culross fault are somewhat ambiguous (Fig. 3). The MDAs are similar and fall near the K-Pg boundary, the traditional age break between the Valdez and Orca Groups (c.f. Davidson and Garver, 2017). The Phanerozoic grain age distribution of the two samples are strikingly similar (Fig. 5B), but they fail the K-S test, perhaps because of the difference in the sample size (n) between the two samples (Gehrels, 2012).

\section{CONCLUSIONS}

The Eaglek fault in northern Prince William Sound is the only strand of the Contact fault that may be a terrane boundary between the Valdez and Orca Groups. Our results show that the Jack Bay a fault in the Valdez Arm area is definitely not a terrane bounding fault and the Culross strand in Kings Bay in Western PWS is ambiguous, and appears to separate rocks with similar MDA's and grain-age distributions. Our preferred interpretation is that the turbidites of the Chugach terrane (Valdez Group) and turbidites of Prince William terrane (Orca Group) should be considered together, and were deposited, accreted to the continental margin, and deformed over a protracted period of time from the Late Cretaceous to Early Eocene.

\section{ACKNOWLEDGMENTS}

This material is based upon work supported by the Keck Geology Consortium and the National Science Foundation. Field work and analyses were funded by NSF Grant "Collaborative Research: RUI: Translation and accretion of the Yakutat microplate and Prince William terrane, Alaska", NSF EAR 1727991. Additional funding was from Keck Geology Consortium NSF Grant No. 1659322,'Geology of the Chugach-Prince William terrane in northern Prince William Sound, Alaska." U-Pb data were collected at the Arizona LaserChron Center, the NSF multi-user facility run by Mark Pecha and George Gehrels at the University of Arizona funded by NSF-EAR Grant No. 1649254. Special thanks to project advisors Dr. Cameron Davidson and Dr. John Garver, and team members Nick Gross-Almonte, Mollie Pope, Victor Garcia, Caitlin Noseworthy, and Will Fisher. 


\section{REFERENCES}

Arkle, J. C.; Armstrong, P. A.; Haeussler, P. J.; Prior, M. G.; Hartman, S.; Sendziak, K. L.; and Brush, J. A. 2013. Focused exhumation in the syntaxis of the western Chugach Mountains and Prince William Sound, Alaska. Geol. Soc. Am. Bull. 125:776-793. doi:10.1130/B30738.1.

Bol, A. J., and Gibbons, H. 1992. Tectonic implications of out-of-sequence faults in an accretionary prism, Prince William Sound, Alaska. Tectonics 11:1288-1300. doi: 10.1029/92TC01327.

Bol, A. J., and Roeske, S. M. 1993. Strike-slip faulting and block rotation along the contact fault system, eastern Prince William Sound, Alaska. Tectonics 12:49-62. doi: 10.1029/92TC01324.

Bradley, D. C.; Kusky, T. M.; Haeussler, P. J.; Goldfarb, R. J.; Miller, M. L.; Dumoulin, J. A.; Nelson, S. S.; and Karl, S. M. 2003. Geologic signature of early Tertiary ridge subduction in Alaska. In Sisson, V. B.; Roeske, S.; and Pavlis, T. L., eds. Geology of a transpressional orogen developed during ridge-trench interaction along the North Pacific margin. Geol. Soc. Am. Spec. Pap. 371:19- 49.

Bradley, D.C., and Miller, M.L., 2006, Field guide to south-central Alaska's accretionary complex, Anchorage to Seward: Anchorage, Alaska Geological Society, 32 p.

Davidson, Cameron, and John I. Garver. "Age and Origin of the Resurrection Ophiolite and Associated Turbidites of the Chugach-Prince William Terrane, Kenai Peninsula, Alaska." The Journal of Geology 125.6 (2017): 681-700. Web.

Dumoulin, J. A., Sandstone petrographic evidence and the Chugach-Prince William terrane boundary in southern Alaska, Geology, 16, 456- 460, 1988

Fisher, W.S., Pope, M.D., Malik, A.M., Garver, J.I., and Davidson, C.M., 2019. Zircon facies in the Paleocene-Eocene Orca Group indicate a provenance link to the Chugach terrane,
Prince William Sound, Alaska. Geological Society of America Abstracts with Program, Cordilleran Section - 115th Annual Meeting, Portland Oregon. v. 51, n. 4. doi: 10.1130/ abs/2019CD-329384

Garcia, Jr., V.R., Stockli, D.F., Davidson, C. and Garver, J.I. 2019. Crystallization ages and geochemistry of the Miner's Bay and Cedar Bay plutons, Prince William Sound, Alaska: Geological Society of America Abstracts with programs, v. 51, Portland, OR.

Garver, J.I., and Davidson, C. 2015. Tectonic evolution of the Prince William terrane in Resurrection Bay and eastern Prince William Sound, Alaska: Short Contributions, Keck Geology Consortium 28th Annual Symposium Volume, Union College, NY.

Gehrels, G., 2012, Detrital Zircon U-Pb Geochronology: Current Methods and New Opportunities, in Tectonics of Sedimentary Basins: Recent Advances, C. Busby and A. Azor, editors, Wiley-Blackwell Publishing, p. 47-62.

Grimm, William. 2015, A tectonic and provenance study of the Chugach-Prince William terrane, Alaska, with specific focus on the Paleogene Orca Group, using $\mathrm{U}-\mathrm{Pb}$ dating of detrital zircons, Senior Integrative Exercise, Carleton College, $\mathrm{MN}$.

Gross Almonte, N., Fisher, W.S., Malik, A.M., Garver, J.I., and Davidson, C.M. 2019. Age and provenance of the Upper Cretaceous to Paleocene Valdez Group of the Chugach terrane from the Richardson Highway and northern Prince William Sound, Alaska. Geological Society of America Abstracts with Program, Cordilleran Section 115th Annual Meeting, Portland Oregon. v. 51, n. 4. doi: 10.1130/abs/2019CD-329673.

Hudson, T.; Plafker, G.; and Peterman, Z. E. 1979. Paleogene anatexis along the Gulf of Alaska margin. Geology 7:573-577.

Jones, D. L.; Silberling, N. J.; Berg, H. C.; and Plafker, G. 1981. Map showing tectonostratigraphic 
terranes of Alaska, columnar sections, and summary description of terranes. U.S. Geol. Surv. Open-File Rep. 81-792, 2 sheets, 20 p., scale 1:2,500,000.

Moffit, F. H., 1954, Geology of the Prince William Sound region, Alaska: U.S. Geol. Survey Bull. 989-E, p. 225-310.

Nelson, S.W., Dumoulin, J.A., and Miller, M.L., 1985, Geologic map of the Chugach National Forest, Alaska: U.S. Geological Survey Miscellaneous Field Studies Map MF1645-B, 16 p., 1 PI., scale 1:250,000.

Nokleberg, W. J., G. Plafker, and S. M. Roeske, Structural analysis and accretionary tectonics of Cretaceous and early Tertiary flysch sequences juxtaposed along the Contact Fault, eastern Chugach Mountains, Alaska, Geol. Soc. Am. Abstr. Programs, 18, 164, 1986

Plafker, G.; Moore, J. C.; and Winkler, G. R. 1994. Geology of the southern Alaska margin. In Plafker, G., and Berg, H. C., eds. The geology of Alaska. Boulder, CO, Geological Society of America, p. 389-449.

Plafker, G.; Jones, D. L.; and Pessagno, E. A., Jr. 1977. A Cretaceous accretionary flysch and mélange terrane along the Gulf of Alaska margin. In Blean, K. M., ed. The U.S. Geological Survey in Alaska: accomplishments during 1976. U.S. Geol. Surv. Circ. 751B:B41-B43.

Roeske, S. M.; Snee, L. W.; and Pavlis, T. L. 2003. Dextral slip reactivation of an arc-forearc boundary during Late Cretaceous-early Eocene oblique convergence in the northern Cordillera. In Sisson, V. B.; Roeske, S.; and Pavlis, T. L., eds. Geology of a transpressional orogen developed during ridge-trench interaction along the North Pacific margin. Geol. Soc. Am. Spec. Pap. 371: 141-169.

Tysdal, R. G., and Case, J. E. 1979. Geologic map of the Seward and Blying Sound quadrangles, Alaska. Reston, VA, U.S. Geological Survey,

$$
12 \text { p., } 1 \text { sheet, scale 1:250,000. }
$$

Winkler, G. R., and Plafker, G. 1975. The Landlock fault: part of a major early Tertiary plate boundary in southern Alaska.In Yount, M. E., ed. U.S. Geological Survey Alaska program, 1975. U.S. Geol. Surv. Circ. 722:49. 